\title{
Diacronie
}

Studi di Storia Contemporanea

$\mathrm{N}^{\circ} 28,4 \mid 2016$

La voce del silenzio

\section{"Karlsson", The Amiable Spy: Swedish experiences of Allied espionage and sabotage during World} War II

\section{Victor Lundberg}

\section{(2) OpenEdition \\ Journals}

Electronic version

URL: http://journals.openedition.org/diacronie/4709

DOI: 10.4000/diacronie.4709

ISSN: 2038-0925

Publisher

Association culturelle Diacronie

\section{Electronic reference}

Victor Lundberg, " "Karlsson", The Amiable Spy: Swedish experiences of Allied espionage and sabotage during World War II », Diacronie [Online], № 28, 4 | 2016, document 4, Online since 29

December 2016, connection on 19 April 2019. URL : http://journals.openedition.org/diacronie/4709 ; DOI : 10.4000/diacronie.4709 


\section{Diacronie}

N. 28 | 4|2016 La voce del silenzio: intelligence, spionaggio e conflitto nel XX secolo

4/

\section{"Karlsson", The Amiable Spy: Swedish experiences of Allied espionage and sabotage during World War II}

\section{Victor LUNDBERG *}

This article deals with an active personality in the European World War II-context, the Englishman and diplomat Peter Tennant. Officially, he served as press attaché at the British legation in Stockholm and become a popular companion in the capital's conviviality with a significant social network. Unofficially, he was called «Karlsson» and led the Swedish section of Special Operations Executive, S.O.E. In this role he organized clandestine espionage and sabotage against German interests. This article primarily uses previously confidential archival sources from the civil Swedish counter-espionage to find out more about Tennant's activities in Sweden during the war and what kind of spy he actually was.

\section{Introduction}

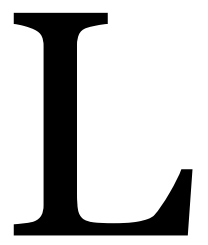

ate Saturday night April 17, 1943, agents from the Swedish counterespionage arrested a man in his thirties in central Stockholm. He was an ordinary industrial worker from Norrköping and had at this particular time visited the British legation in the fashionable area of Östermalm. There he had got a mysterious briefcase, which he carefully dared to open first when he arrived to his hotel room downtown. In the following moment, agents kicked in the door and a new chapter began in the tangled history about Sweden and the World War II. 
At this time, Sweden found itself in a precarious situation. The country lay in the middle of a geographical field of tension, surrounded by the two heavy-armed superpowers U.S.S.R. in the north and east and Germany in the south and west. Especially from a geo-political and military perspective the country was very vulnerable. The combination of partly weak and obsolete armed forces with a long coastline and a lot of archipelagos and islands was fragile and problematic from this point of view. Thus the public sphere and production of news during the war was characterized by anxiety and rumors, and the country maintained a high level of military preparedness and mobilization. The Swedish authorities were working at full speed to cope with a passive state of war: migration, espionage, sabotage, smuggling, rationing, censorship, and so forth.

Although, regarding social relations, economy and politics the Swedish society was in comparison rather stable. Its welfare state had started to be constructed and the social-reformist ideas of Alva and Gunnar Myrdal had a great impact those days. The social democratic Prime Minister Per Albin Hansson led a grave coalition government and tried together with the non-political diplomat Christian Günther, who served as Minister of Foreign Affairs, to keep an indulgent and low profile in foreign affairs. While the informal guiding principle was consensus outward, correction inward, the official Swedish policy was non-alignment and neutrality. But nevertheless, it concealed generous appeasement towards particularly The Third Reich due to historically rooted cooperation and relations in various ways ${ }^{1}$.

With all this in mind, Sweden was during the war an important strategic outpost for the belligerent countries, perhaps even most for the Allies, and it developed to be a besieged and thrilling battleground for information and propaganda warfare, intelligence services and espionage: «The great powers were eager to exploit opportunities to damage their enemies through espionage, sabotage and counterintelligence operations on Swedish territory ${ }^{2}$. Stockholm was in this matter in the eye of the storm. The capital of Sweden was one of few places in Europe where all significant intelligence services were represented during the war, it was in fact a center for diplomacy and espionage: «a Nordic Casablanca»3. In this context the British diplomat Peter Tennant (1910-1996) was a familiar face. Throughout the war he

\footnotetext{
${ }^{1}$ AGRELL, Wilhelm, «Sweden and the dilemmas of neutral intelligence liaison», in The Journal of Strategic Studies, 29, 4/2006, pp. 633-651.

${ }^{2}$ GILMOUR, John, Sweden, the Swastika and Stalin. The Swedish Experience in the Second World War, Edinburgh, Edinburgh University Press, 2010, p. 134.

3 CARLBERG, Ingrid, Raoul Wallenberg. The Biography, London, MacLehose Press, 2016, p. 142.
} 
formally served as press attaché at the British legation. Informally, he was called "Karlsson" and operated as leader of the British espionage and sabotage organization Special Operations Executive, S.O.E., in Sweden 4.

The purpose of this article is to investigate and contextualize Peter Tennant's activities in Sweden during World War II, and with this primarily try to map his informal activities within the S.O.E. in Sweden. By this, the aim is to deepen the understanding of espionage and its conditions at a crucial stage in the history of modern warfare. Tennant's years in Sweden have formerly been outlined to a limited extent and he has been described as an unreliable yet popular secret agent, surrounded by an aura of flamboyance, excitement and mystery5. The explorative research questions that arise here are thus firstly about what he actually did in Sweden and secondly about what kind of spy he actually was. Due to the incomplete and fragmentary archival situation around S.O.E. in Sweden it is though impossible to reach any kind of definitive answer to these questions. This methodological limitation leads to that the article's results should be understood as preliminary and related to a forthcoming and wider research project of mine about S.O.E.'s activities in Sweden, where British sources will be included to a greater extent.

From a theoretical-analytical view, this article takes a social-psychological approach to what espionage and spying are about. Thus, its mainly technical duties such as surveillance, interception, deciphering, and bargaining are deeply embedded in risky socio-cultural contexts in which the behavior of the spy are decisive. In this sense, spying is considered world's «second oldest profession» and the core of espionage about accessing or gathering information secretly without the owner's will or awareness in order to find clandestine knowledge and advantages in relation to its counterpart ${ }^{6}$. Central to spying is also activities such as misinforming and planting rumors and factoids that mislead and establishes false knowledge ${ }^{7}$. During the 1900 s espionage and counter-espionage became indispensable parts of modern warfare, not least because of

\footnotetext{
4 FOOT, Michael Richard Daniell, «Obituary: Sir Peter Tennant», in The Independent, URL: < http://www.independent.co.uk/incoming/obituary-sir-peter-tennant-5585803.html > [consultato il 28 dicembre 2016].

5 AGRELL, Wilhelm, Stockholm som spioncentral, Lund, Historiska Media, 2006, pp. 70-73, 103-105.

${ }^{6}$ KNIGHTLEY, Phillip, The Second Oldest Profession. Spies and spying in the twentieth century, London, Pimlico, 2003.

7 FARAGO, Ladislas, War of Wits. The anatomy of espionage and intelligence, New York, Funk \& Wagnalls Company, 1954, pp. 153-154.
} 
the scope of World War II and the coming digital revolution with the completely new conditions of warfare that it brought ${ }^{8}$.

\section{Stockholm and the Swedish counter-espionage during World War II}

Stockholm's role as an European «spy center» during World War II was reflected in a increasing number of foreigners and diplomats staying in the city. As an example, the workforce at the American legation grew from less than 10 in the beginning of the war to around 400 in the end. But as Ladislas Farago has pointed out, very few of the spies who «flocked» here were (except from the Russians who have a long tradition of being shamelessly interested in Sweden for military reasons) interested in Swedish conditions 9 . Instead they used Sweden and its capital as a platform for various confidential activities and operations both inside and outside its national borders. Stockholm functioned as a «staging ground and a marketplace» for espionage and «complicated liaison» between actors and organizations that officially not existed at all ${ }^{10}$.

The main actors in this drama were all positioned in the central area of Östermalm. Besides the Americans (including O.S.S.) at Strandvägen 7 and the Britons (including S.O.E.) at Strandvägen 82, the Russians and their organizations G.R.U. and N.K.V.D. were housed at Villagatan 7 while the Germans ran shady business from bases in «Büro Wagner» at Nybrogatan 27 and in the official German legation at Hovslagargatan 2. In addition, the Britons had a discrete office for S.I.S. at Birger Jarlsgatan 12, camouflaged as a passport office. The Headquarter of Sweden's military intelligence was a small and confidential organization with different and relatively autonomous subsections that had various and unclear tasks. It was suitably located in the middle of these blocks, in Grå Huset/Generalstaben (The Grey House/The General Staff) at Östermalmsgatan $87^{11}$. In this context, the Allied had to handle two agendas and enemies simultaneously: on one hand their anti-Nazi beliefs and the Germans who especially during the early war years

\footnotetext{
${ }^{8}$ FARAGO, Ladislas, Burn After Reading. The Espionage of World War II, Annapolis, Naval Institute Press-Bluejacket Books, 2003; FERRIS, John, After the RMA: Contemporary Intelligence, Power and War, in KASSIMERIS, George, BUCKLEY, John (ed.), The Ashgate research companion to Modern Warfare, Farnham, Ashgate Publishing-Routledge, 2010. 9 FARAGO, Ladislas, The Game of the Foxes. British and German intelligence operations and personalities which changed the course of the Second World War, London, Hodder and Stoughton, 1972, pp. 521-531, p. 522. 10 AGRELL, Wilhelm, «Sweden and the dilemmas of neutral intelligence liaison», cit., pp. 637638.

${ }^{11}$ AGRELL, Wilhelm, Stockholm som spioncentral, cit., pp. 7-9.
} 
advanced their positions seriously in Sweden and Scandinavia, and on the other hand their anti-communist strategies and the Russians who became a particularly more urgent threat after the turning point of the war in 1943, manifested in the Battle of Stalingrad and the downfall of Nazi-Germany.

The Swedish authorities' response to this foreign spy invasion was massive. During the war an enormous counter-espionage apparatus was mobilized. Aside the military intelligence, the Swedish counter-espionage was then mainly organized through a new civil security service: Allmänna Säkerhetstjänsten, A.S (the General Security Service). With the main aim, at least initially, to map and handle state enemies from the political left, this organization was inaugurated in September 1939 after initiatives that originated from the social democratic government and influential anti-communist interests within the state authorities and enterprise. The organization was directly subordinated the government and led by the controversial police officer Eric Hallgren: a notorious and heavy-handed communist-hunter and head of the criminal police in Stockholm during the 1920s. This peculiar origins of A.S. become logical in the light of a long tradition of fear of Russians, Bolsheviks, socialists and "communism" in Swedish political life and public sphere.

A.S. had a character of civil pseudo-police, acting intrusively in loose legal reins and with an unclear relation to the regular police organization. Its operations were divided into three subsections: the Central Bureau that controlled and censored all kind of communications in society; the Surveillance Bureau that were watching and monitoring suspect organizations, persons or phenomena in society; and the Expedition Bureau that took care of administration, registration and other archival tasks. When this sophisticated contra-espionage organization reached its peak in 1943, it employed over 1.000 people in different positions and had in addition a large number of listeners, informers and other associates on its payroll. In total, A.S. between 1939 and 1945 opened and read 50 million items of mail, stopped over 3.000 telegrams and censored 5.0oo, intercepted 11 million phone calls, and registered over 80.000 «politically unreliable» Swedes and foreigners ${ }^{12}$.

When the existence of A.S. was revealed in 1943, the public indignation was severe and fierce critique was directed against its pliable and spineless principles. While Germans were treated friendly and soft, and Britons and other Allies were monitored hard, in the beginning of the war, the circumstances were the reverse at the end. Because, after the Battle of Stalingrad the Swedish counter-espionage instead became

${ }_{12}$ FLYGHED, Janne, Rättsstat $i$ kris. Spioneri och sabotage i Sverige under andra världskriget, Stockholm, Federativs förlag, 1992, pp. 265-322. 
more friendly towards Britons and the Allies and more sharp towards Germans and their sympathizers. Nevertheless, the counter-spies within A.S. were quite successful in their mission to watch over unruly people and fiddly events during the war, or as John Gilmour puts it: «keeping the lid on a bubbling cauldron of spies and saboteurs» ${ }^{13}$.

\section{The amiable spy}

One of the persons that the Swedish counter-espionage kept an extra eye on was Peter Tennant. On November 1, 1939, A.S. registered that he had been enrolled at the British legation since September 26 when he arrived in Charlottenberg, close to the Norwegian border. At the same time, they noted that his wife Hellis Tennant already had arrived in the end of July via Helsingborg, near Elsinore in Denmark. Mr. Tennant's pro-British activities immediately began to interest A.S. and beside the regular surveillance they in August 1940 decided to request control of his mail. A few weeks later, in September 1940, they started the interception of his phone, which they continued to do until January $17,1945^{14}$.

Just a few days after his arrival he was interviewed by Swedish journalists and expressed confidence with his new assignment and trivialized the war as something he barely had noticed yet ${ }^{15}$. His formal duties as press attaché at the legation was to represent, embrace, promote and defend British interests in Sweden and to disseminate and collect information and news: «As my job was to promote the British cause publicly it was also important to know what not to promote and this meant keeping in touch with everybody» ${ }^{16}$. As a consequence, he during his years in Stockholm developed a large network of contacts with politicians, directors, policemen, civil servants, artists, military officers, authors, and academics. In A.S.'s mapping of this network, several hundred many well-known Swedes - as the liberal and anti-fascist authors, journalists and editors Carl Adam Nycop and Åke Tulstrup, the author and Nobel Prize-winner (1951) Pär Lagerkvist, and the beloved actor and artist Stig Järrel - are listed with their personal relationship to Tennant carefully noted ${ }^{17}$.

\footnotetext{
${ }_{13}$ GILMOUR, John, Sweden, the Swastika and Stalin, cit., p. 136.

${ }^{14}$ Swedish National Archive, the Archive of the Security Police, Peter Tennant's personal file (P1596): Memorandum, 01-11-1939; Form, 15-08-1940 (Folder 1A); Summary, 12-03-1945 (Folder 2A).

${ }^{15}$ Aftonbladet, 29 September 1939.

16 TENNANT, Peter, Touchlines of War, Hull, The University of Hull Press, 1992, p. 58.

${ }^{17}$ Swedish National Archive, the Archive of the Security Police, Peter Tennant's personal file (P1596): Name lists, undated (Folder 2A).
} 
With his solid middle-class background - born and raised in Hoddesdon, Hertfordshire, and academically specialized in Scandinavian societies and languages at Marlborough, Cambridge and Queens - Tennant easily established as a distinguished and socially competent gentleman in the public sphere and conviviality of Stockholm. He often made great impression with his fluent and flawless Swedish and imitations of different regional accents. A recurring and popular event that he arranged was wellattended press evenings at the British Legation. Here he, in front of an audience of invited journalists and various anglophiles from the cultural elite, told news in his way and announced Britain's view on the war and the world.

Beside this, he was also engaged in other, more confidential boyish pranks from the current spy handbook ${ }^{18}$. Spreading itching powder at Grand Hotel, in high-ranked German military officers underwear was one of them ${ }^{19}$. A second was to send fake announcements and meeting invitations to Swedish Nazi-sympathizers. A third was to mass-produce 50 ooo falsified German stamps, picturing the Gestapo chief Himmler instead of Reich Chancellor Hitler, and use them to post «black propaganda» with faked war-news around Germany. A fourth was to spread false rumors and disinformation among pro-German Swedes about the Allies preparing a forthcoming embarkation with troops on Norway's west coast. This was a part of the comprehensive and successful transnational operations Graffham and Fortitude 2 that deceived the Germans to retain troops in Norway and therefore made the invasion of Normandy in June 1944 possible ${ }^{20}$.

While all this aimed to confuse, demoralize and mislead, Tennant also acted in other ways behind the scene. In this he built close and useful relations with key persons at important positions in the Swedish society. One of those was the world famous and legendary Swedish criminal investigator and forensic specialist Harry Söderman, in the history books most known as "Revolver-Harry". He had by his central position in International Criminal Police Commission (I.C.P.C., from 1956 Icpo-Interpol) a broad international network, including the Gestapo-leadership in Berlin as well as the Scotland Yard in London. Among many things, he was during the war leading the education of an extensive paramilitary Norwegian resistance-troop on Swedish

\footnotetext{
${ }^{18}$ RIGDEN, Denis, How To Be A Spy. The World War II SOE Training Manual, Toronto, The Dundurn Group, 2004.

${ }_{19}$ In the manual for S.O.E.-agents, the use of this rather effective itching powder, made from «tiny seed hairs» is explained: RIGDEN, Denis, How To Be A Spy, cit.p. 24.

${ }^{20}$ Dagens Nyheter, 1 October 1989; TENNANT, Peter, Touchlines of War, cit., pp. 34-35.
} 
territory, «polititroppene», that soon consisted of 15.000 insurgents with a lot of heavy weapons and vehicles ${ }^{21}$.

Tennant and Söderman apparently reached a near relation. They shared deep proAllied interests and combined behind their formal duties as an «odd duo» business with pleasure ${ }^{22}$, not least when it came to food and beverages: «He became a close friend, a sailing companion on my boat Valkyrian and an eating, drinking and singing gastronome» ${ }^{23}$. Of course it was a notable advantage for S.O.E. that their man in Stockholm were socializing in private with the head of the Criminal Technical Institute of Sweden. And with a concise but cryptic formulation, which probably contains a lot of untold information, Tennant afterwards underlined that Söderman throughout the war was a «friend and ally for whose solid support we were most grateful» 24 . What is not mentioned here is that it actually was Harry Söderman who was responsible for the criminal technical investigations that followed some of the sabotage actions that took place in Sweden during the war, and which S.O.E. were considerably suspected to have organized.

Another person that Tennant developed a significant connection to was the influential businessman and weapon-dealer John Helge Walter. He had built a fortune selling American can openers to the Swedish army and was when the war broke out enlisted as negotiator and courier by the Swedish government with the task to buy new modern destroyers from Italy to the outdated Swedish Navy. However, the whole affair ended up in diplomatic jumble when the destroyers were seized in June 1940 near the Faeroes by the British Navy on their way from La Spezia to Gothenburger, and in springtime 1943 Walter was sentenced to penal servitude for espionage. According to the Swedish counter-espionage, he had forewarned Tennant about the upcoming, secret and intricate destroyer-affair and even leaked information to him about classified discussions inside the parliamentary Foreign Policy Council (Utrikesnämnden) ${ }^{26}$. In the interrogations, Walter saw Tennant as a nice but rather shallow acquaintance that he had met in some cocktail parties at the home of his close

${ }^{21}$ JOHANSSON, Anders, Den glömda armén. Sverige-Norge 1939-1945, Stockholm, Fisher \& Co., 2008, pp. 58-75; SÖDERMAN, Harry, Skandinaviskt mellanspel. Norska och danska trupper i Sverige, Stockholm, Forum, 1945, pp. 102-127; TENNANT, Peter, Touchlines of War, cit., pp. 166-173.

${ }_{22}^{2}$ JOHANSSON, Anders, Den glömda armén, cit., p. 61 (quotation, my translation).

23 TENNANT, Peter, Touchlines of War, cit. p. 163.

24 Ibidem, p. 162.

25 GILMOUR, John, Sweden, the Swastika and Stalin, cit., pp. 215-216.

${ }^{26}$ Swedish National Archive, the Archive of the Security Police, Peter Tennant's personal file (P1596): Interception protocol, 01-04-1941; Interception protocol, 19-03-1941; Interrogation report, 19-12-1942 (Folder 1A). 
friend, countess Amelie Posse-Brázdová - whom he in 1938 had helped escape from Czechoslovakia to Sweden after the Nazi occupation and whose son he had helped escape to England after killing a Nazi in Stockholm's docklands ${ }^{27}$.

A third influential person that Tennant developed a close relationship to was the already named Amelie Posse-Brázdová. She played a political key role in the anglophile and pro-Allied Swedish opposition to Nazism and the Third Reich. During the war years, she was a loud and well-known anti-fascist debater in Sweden and an intellectual and cultural personality with many significant contacts in the upper political establishment. She lived an eventful life, married the Czech artist Oskar Brázda in 1915, become a friend of the first president of Czechoslovakia, Tomás Garrigue Masaryk, and was beside her anfi-fascist beliefs even eagerly dedicated in the striving for Czechoslovakian independence ${ }^{28}$. On a personal level she was godmother of Tennant's children and described him heartily as: a «talented and adorable» man who «whole Stockholm, specifically its artistic and intellectual world, communed with». Their own relation she declared as based on «mutual sympathy» with «dangerous and dubious things behind $[\ldots]{ }^{29}$. It was also she that came up with the idea to mask Walter's and Tennant's identities as (initially alternately) "Pilqvist" and "Karlsson" in order to confuse the A.S.-agents ${ }^{30}$.

Obviously, Tennant was very popular and gracious, and extraordinary successful in building close human relations. This makes sense in the light of Carson Eoyang's analyses of espionage as «a complex and elaborate pattern of linked behaviors» ${ }^{31}$. Thus, appearing harmless, trustworthy and amiable as a spy, could be about to set up classical honey traps, using sexual devotion to deceive, disarm, and access information, but is essentially a matter of ingratiation which Stan A. Taylor and Daniel Snow have pointed out as one fundamental dimension of espionage: «[...] in order to make favorable impressions on someone whose approval is desired»32. To sum up, amiability in this

27 TENNANT, Peter, Touchlines of War, cit., pp. 74-75, 229-251. Swedish National Archive, the Archive of the Security Police, Peter Tennant's personal file (P1596): Interrogation report, 02/04-12-1942 (Folder 1A).

28 STRÖMBERG KRANTZ, Eva, En ande som hör jorden till. En bok om Amelie Posse,

Stockholm, Carlsson, 2010.

29 POSSE, Amelie, Atskilligt kan nu sägas, Stockholm, Bokförlaget Natur och Kultur, 1949, p. 337 (quotation, my translation); TENNANT, Peter, Touchlines of War, cit., pp. 73-78.

30 Swedish National Archive, the Archive of the Security Police, Peter Tennant's personal file

(P1596): Memorandum about Karlsson, 20-03-1941 (Folder 1A).

${ }^{1}$ EOYANG, Carson, Models of Espionage, in SARBIN, Theodore R., CARNEY, Ralph M., EOYANG, Carson (ed.), Citizen Espionage. Studies in Trust and Betrayal, Westport (Connecticut), Praeger Publishers, 1994, p. 85.

32 TAYLOR, Stan A., SNOW, Daniel, «Cold war spies: Why they spied and how they got caught», in Intelligence and National Security, 12, 2/1997, pp. 101-125, p. 106. 
sense is crucial for a spy of Tennant's kind, a spy with the masculine strategy to seduce and bind other person's wishes and to create desire for cooperation and connection 33 .

\section{Sabotage, stay-behind and other underground activities}

Peter Tennant's primary pursuit in Stockholm during the war was actually not his duty as press attaché. His sharp mission was instead - recruited by Charles Hambro and in the beginning together with Malcolm Munthe - to organize S.O.E. in Scandinavia. According to Max Hastings, S.O.E. was originally about a new kind of secret war - «a new kind of war with new men and new means» - with guerilla warfare, sabotage, burglary, vandalism, assassinations and other forms of resistance towards Germany all over Europe. The initiative behind S.O.E. was carefully considered by Prime Minister Churchill and based on some clear and distinct objectives with focus on making «mayhem across Europe» - or as Churchill himself expressed this: «to set Europe ablaze» 34 .

S.O.E. started its transnational activities in July 1940 and in October their ambitions in Scandinavia was straightened when Tennant was appointed to lead its three main activities: subversive propaganda ( $\mathrm{SO}$ 1), subversive warfare ( $\mathrm{SO} 2$ ), and overt propaganda (MOI)35. According to Tennant, they recruited «safe-breakers, forgers and other splendid representatives of the criminal classes» as well as «lawyers, merchant bankers and dons»36. Their activities were thus rather multifaceted and inventive, but according to Hastings anyway «more effective» than S.I.S./MI6 and driven «by abler people» 37 .

Since the Swedish neutrality policy allowed extensive German train and sea transports of commodities, war equipment and troops through Sweden, one of two main tasks for S.O.E. was to sabotage and destroy German interests and support

33 CALÁS, Marta B., SMIRCICH, Linda, «Voicing Seduction to Silence Leadership», in Organization Studies, 12, 4/1991, pp. 567-602.

34 HASTINGS, Max, The Secret War. Spies, Codes and Guerillas 1939-45, London, William Collins, 2016, pp. 260-264, quotations pp. 261, 264. About the fundamentals and organization of S.O.E. se also: FOOT, M.R.D., SOE. An Outline History of the Special Operations Executive 1940-1946, London, The Bodley Head, 2014, pp. 1-20; JEFFERY, Keith, The Secret History of MI6, New York, The Penguin Press, 2010, pp. 352-358; STAFFORD, David, Britain and European Resistance, 1940-1945. A survey of the Special Operations Executive, with Documents, London, Thistle Publishing, 2013, pp. 238-239.

35 CRUICKSHANK, Charles, $S$ O E in Scandinavia, Oxford-New York, Oxford University Press, 1986, p. 61.

${ }_{36}$ TENNANT, Peter, Touchlines of War, cit., p. 146.

37 BOYCE, Fredric, EVERETT, Douglas, SOE. The scientific secrets, Stroud, The History Press, 2009, pp. 69-88; HASTINGS, Max, The Secret War, cit., p. 261. 
functions on Swedish territory. So, despite that S.O.E. in Sweden as well as elsewhere officially didn't even exist, it soon started to happen violent things:

- April 17, 1941: a bomb attack at Gudå train station, near Meråker in Norway, close to the border between Sweden and Norway. This attack was a part of Operation Barbara but failed completely. Instead of a big German transport train, the target became a small Norwegian railcar that happened to be in the way. The unsuspecting Norwegians inside were injured by shattered glass but survived fortunately. This was a fiasco for both S.O.E. and Scandinavian resistance and was concealed in darkness ${ }^{38}$.

- July 19, 1941: a bomb attack against a transport train at the Station in Krylbo in the landscape Dalarna in central Sweden. The train had 59 wagons on its way from Charlottenberg to Torneå in northern Finland, carrying German ammunition, field kitchens, cannons, gasoline, and office supplies. The devastation at the railyard was apocalyptic but like a miracle (or an intention?) only 13 persons were lightly injured since the explosion took place at five o'clock in the morning. In the following investigation, Harry Söderman argued that a sabotage could be excluded - «not even a hypothesis» - and that the underlying cause probably was an accident due to overheating 39 .

- September 17, 1941: a bomb attack against the three Swedish destroyers $H M S$ Göteborg, HMS Klas Uggla and HMS Klas Horn, anchored in Hårsfjärden, in the south archipelago of Stockholm. All of them sank and Klas Uggla was totally destroyed. 33 persons died, both officers and conscripts, and 17 persons were heavily injured. What actually took place has never been thoroughly investigated or illuminated. The Navy Headquarters' secret inquiry, most based on hypotheses and interrogation of contradictory eyewitnesses, does not actually clarify anything ${ }^{40}$.

Tennant and his S.O.E.-colleagues, the Britons Malcolm Munthe, George Binney and Henry McLeod Threlfall, have in various contexts been pointed out as responsible here, but they have never, and that is important to emphasize, been officially proven or

${ }^{38}$ CRUICKSHANK, Charles, $S$ O E in Scandinavia, cit., p. 191.

${ }^{39}$ Swedish National Archive, the Archive of the Security Police, Incident-file «The KrylboCatastrophe» (IC2r): Investigation report, 28-07-1941, p. 9 (quotation, my translation), (Supplement). MUNTHE, Malcolm, I krig är allt tillåtet. Som sabotör $i$ Finland, Norge och Sverige, Stockholm, Lars Hökerbergs Bokförlag, 1954, pp. 205-209.

${ }^{40}$ Swedish National War Archive, the Archive of the Navy Headquarter, the Operation Division, Series F II, Documents regarding the Destroyer Accident 1941, volume 3. 
sentenced. Nevertheless, they were undoubtedly the ones who had the greatest interest, expertise and capacity to carry out these operations. The Allies, and particularly the Britons, were very annoyed by and concerned that the Germans transported troops and weapons through Sweden, and not at least that the Swedish Navy escorted German freighters and warships on their seaway to Finland and Norway. A weakening of the Swedish fleet thus also was an indirect weakening of the German ${ }^{41}$.

Beside this, British agents with connections to S.I.S./M.I.6. were also involved in the awkward «Rickman-affair» a year before, when the plan to blow up the important iron shipping harbor in Oxelösund failed. In retrospect Tennant declared his innocence and meant that they hadn't failed if he had participated ${ }^{42}$. A year after, in the summer 1942, the likewise embarrassing «Blackman-affair» was unveiled. Agent Threlfall then had equipped and instructed the dubious Swedish sailor, and previously sentenced violent criminal, Ivan Blackman to place firebombs on German ships in Gothenburg and to blow up the floodgates of the Kiel Canal. Even this plan failed and all involved were arrested, all except Threlfall43. The Swedish counter-espionage traced Tennant's involvement in this through persistent shadowing when A.S.-agents eavesdropped on Tennant and Threlfall when they were having dinner at the famous restaurant Bacchi Wapen in Gamla Stan in Stockholm, late evening February 23, 194244.

The other of the two main tasks for S.O.E. in Sweden during the war years was to build up and organize a clandestine stay-behind network of trustworthy Swedes. In case of a German occupation, this should operate as the backbone of a decentralized resistance network. A central figure in this was Amelie Posse-Brázdová. In April 1940, at the same time when Germany attacked Denmark and Norway, she founded the (actually not so) secret anti-Nazi association the Tuesday Club (Tisdagsklubbeln) in Stockholm, where the cultural elite met every Tuesday to channel their indignation about the Sweden's pro-German foreign policy. Here, also Tennant showed up «by accident» at the first constituting meeting 45 .

${ }^{41}$ FLYGHED, Janne, Rättsstat $i$ kris, cit., pp. 414-416.

42 Dagens Nyheter, 1 October 1989; CRUICKSHANK, Charles, $S$ O E in Scandinavia, cit., pp.

33-43; TENNANT, Peter, Touchlines of War, cit., pp. 126-132.

43 FORSBERG, Tore, Spioner och spioner som spionerar på spioner. Spioner och kontraspioner i Sverige, Stockholm, Hjalmarsson \& Högberg Bokförlag, 2003, pp. 148-149; MEURLING, Per, Spionage och sabotage i Sverige, Stockholm, Lindfors Bokförlag, 1952, pp. 176-182.

44 Swedish National Archive, the Archive of the Security Police, Peter Tennant's personal file

(P1596): Memorandum about monitoring of Threlfall, Tennant and Taub et al, 23-02-1942, p. 2, 4 (Folder 1A).

45 GILMOUR, John, Sweden, the Swastika and Stalin, cit., p. 141; TENNANT, Peter, Touchlines of War, cit., pp. 76-82, p. 76. 
According to the Swedish counter-espionage, Posse-Brázdová and her fellows were primarily a harmless gathering of confused middle-class antifascists with embarrassing attitudes ${ }^{46}$. But through mapping their activities, A.S. could trace and unravel a much more severe tangle: a network on the shadow side of the club with active syndicalists and political refugees from Czechoslovakia and Norway in the core and the radical social democrat K.E.G.J. from Norrköping in the center47. As initially mentioned he was arrested April 17, 1943, in Hotell Blå Bandet at Mäster Samuelsgatan 68 in central Stockholm. In his mysterious briefcase the door-kicking agents from A.S. found: «proAllied propaganda, a battery, a radio transmitter, a circuit diagram, a key and a headphone» ${ }^{4}$. The next day, totally 23 persons were simultaneously arrested in eight cities around Sweden and in the subsequent investigation a complex pattern emerged. In this, the extent of Tennant's role was not really clarified even if he nevertheless appeared as the mastermind. For example, he besides the briefcase also had given to K.E.G.J. a secret encryption key:

$$
\begin{aligned}
& \text { The(1) owl(2) a the(4) pussy(5) cat(6) went(7) to(8) sea(9) in(10) a(11) } \\
& \text { beautiful(12) sea(13) green(14) boat(15) with(16) lots(17) of(18) honey(19) and(20) } \\
& \text { plenty(21) of(22) money(23) wrapped(24) up(25) in(26)49. }
\end{aligned}
$$

K.E.G.J. had no idea why the third word was uncompleted and lacked a number. He neither knew how to use this nor the content of the briefcase. His connection with Tennant and the British Legation was strictly about his trip to England and a labor union event. But according to the interrogation with Posse-Brázdová, who said she wasn't at all familiar with any syndicalists, she and Tennant had discussed the idea of a stay-behind organization with radio transmitters already in 1941, and then Tennant had promised both financial and technical support - and a discrete hideaway at his vessel Valkyrian somewhere in the archipelago of Stockholm ${ }^{50}$.

\footnotetext{
${ }^{46}$ Swedish National Archive, the Archive of the Security Police, Amelie Posse-Brazdova's personal file (vol. 595, P2144): Memorandum/Meeting summary, 23-04-1943, p. 2 (Folder 6). 47 K.E.G.J. is the person's name initials. Due to ethical considerations, I do anonymize his identity here.

${ }^{48}$ Swedish National Archive, the Archive of the Security Police, Peter Tennant's personal file (P1596): Memorandum about an organization..., 21-05-1943, pp. 65-66 (quotation, my translation), (Folder 1R).

49 Swedish National Archive, the Archive of the Security Police, Peter Tennant's personal file (P1596): Memorandum about an organization..., 21-05-1943, p. 63 (quotation), (Folder 1R). ${ }^{50}$ Swedish National Archive, the Archive of the Security Police, Peter Tennant's personal file (P1596): Memorandum about an organization..., 21-05-1943, pp. 84-85 (Folder 1R). Se also: CRUICKSHANK, Charles, $S$ O E in Scandinavia, cit., pp. 59-68.
} 
In June 1943, the Court in Stockholm sentenced K.E.G.J. to two months in prison with three years probation for illegal holding of radio equipment. He admitted holding but denied any involvement in espionage or conspiracies. Neither Tennant nor PosseBrázdová he claimed to know well or trust51. The actual extent of this espionage network is unclear. How many radio transmitters Tennant had the opportunity to hand out and to whom, or how many operators that were instructed and prepared in K.E.G.J.'s and Posse-Brázdová's network, is hard to know. However, it became clear that the activities foremost were ran by syndicalists and political refugees - but notably not any communists. As David Stafford points out, anti-communism became an increasingly important part of S.O.E.'s guiding principles: «SOE was an ideological as well as a strategic force» $5^{2}$. First and foremost this anti-communism had more to do with the upcoming Cold War, and the competition between the intelligence services of U.S.A. and U.S.S.R., and less to do with communists as truly subversive and dangerous elements. Therefore, it was probably not a coincidence that Tennant, despite that communists were the most active and eager anti-fascists and anti-Germans, primarily tied syndicalists to himself and engaged them in his stay-behind network. Their feature as very reliable both anti-fascists and anti-communists, probably suited Tennant, S.O.E. and the British interests unusually well. From their perspective, reliable Swedes were rare.

\section{Conclusion}

Peter Tennant stayed with his family in Stockholm until March 1945. Then he was reluctantly relocated to Paris and installed as Information Counselor: «In a way it was sad not to be in at the kill in Sweden with the defeat of the Nazis together with that select band of old friends». But he was anyway pleased and confident in his and S.O.E.'s achievements: «Our activities played no small part in building up a spirit of resistance to Nazi domination»53. Short before the farewell, he posed smiling together with his wife in Swedish newspapers, taking goodbye and being honored as the best and most popular foreign diplomat in Sweden ever54.

${ }^{51}$ Swedish National Archive, the Archive of the Security Police, Peter Tennant's personal file (P1596): Protocol Extract, Stockholm Court, 30-06-1943; Interrogation protocol, 18-04-1943, p. 8 (Folder 1A).

$5^{2}$ STAFFORD, David, Britain and European Resistance, cit., p. 244.

53 TENNANT, Peter, Touchlines of War, cit., pp. 270, 272 (quotations).

54 E.g. Expressen, 6 February 1945. 
Whatever the case, he undoubtedly put deep imprints in Sweden - in different ways. On one hand, he was an ingenious networker where the friendship with "Revolver-Harry" is extraordinary notable. On the other hand, he was a cunning chameleon who very likely was involved in shady and illegal activities without getting burned. The Swedish counter-espionage was on their side fully occupied with him and his colleagues. In this, they had to develop and test new methods when it came to surveillance, infiltration, phone interception and mail control. These experiences later became very important and the methods were widely implemented during the late 1900's when the Swedish counter-espionage met the threats of the Cold War.

Furthermore, it is obvious that Tennant seems to fit exceptionally well into his contemporary template of the modern and ideal spy with high morale, good judgment and an ability both to inspire collaboration and lead others and to bluff and mislead 55 . The alleged importance of these masculine behavioral dimensions of espionage is also emphasized in the contemporary instructions for S.O.E.-agents: How to Be a Spy. But in relation to that, Tennant differed obviously in his performance and behavior: «Be inconspicuous. Avoid all limelight by being an 'average' citizen in appearance (height, clothes) and conduct (drink, women)»56. On the contrary, Tennant sought the limelight and was anything else but an «average» and mediocre "Karlsson".

World War II created new transnational intelligence and espionage alliances that played a significant role during the rest of the 1900 s and the Cold War57. But we still know very little about this. In Sweden, the detailed traces of S.O.E.'s and Peter Tennant's activities seem to be fairly well cleaned out from the national archives. For, in the aftermath there were no general or specific interests at all to investigate this. Tennant was actually one of the moral and energetic heroes of the war and the reconciliation in Sweden was about other circumstances. This is also why the sabotages in Krylbo and at Hårsfjärden have been historically named as «catastrophes» and «accidents». Thus, something inexplicable that according to the official historical narrative of Sweden during World War II only just happened. But nothing is inexplicable and nothing just happens. Peter Tennant knew this certainly well when he gave the mysterious briefcase to K.E.G.J. the late evening in April 1943, in Stockholm. What it contained, we however know now.

\footnotetext{
55 FARAGO, Ladislas, War of Wits, cit., pp. 187-188.

${ }^{6}$ RIGDEN, Denis, How To Be A Spy, cit., p. 39.

57 JEFFREYS-JONES, Rhodri, In Spies We Trust. The Story of Western Intelligence, Oxford, Oxford University Press, 2015, p. 94. RICHELSON, Jeffrey T, A Century of Spies. Intelligence in the Twentieth Century, New York-Oxford, Oxford University Press, 1995, p. 215-217.
} 


\section{* The author}

Victor Lundberg (born 1976) is Doctor of Philosophy in History at Lund University 2008 and Senior Lecturer/Assistant Professor at the Department of Global Political Studies at Malmö University, Sweden. His research lies in the intersection between modern political history, history of ideas, labor history, military history and gender history, and deals primarily with various forms of political radicalism and militarism and various aspects of ideology of work in society. Currently, his research focus on fascism and anti-fascism, and on structures of power in working life. He is also engaged in bunker archaeological research on post-militarian places around Sweden.

URL: < http://www.studistorici.com/progett/autori/\#Lundberg >

\section{Per citare questo articolo:}

LUNDBERG, Victor, «"Karlsson", The Amiable Spy: Swedish experiences of Allied espionage and sabotage during World War Il», Diacronie. Studi di Storia Contemporanea : La voce del silenzio: intelligence, spionaggio e conflitto nel $X X$ secolo, 29/12/2016,

URL:< http://www.studistorici.com/2016/12/29/lundberg_numero_28/ >

Diacronie Studi di Storia Contemporanea $\Theta$ www.diacronie.it

Risorsa digitale indipendente a carattere storiografico. Uscita trimestrale. redazione.diacronie@hotmail.it

Comitato di redazione: Jacopo Bassi - Luca Bufarale - Antonio César Moreno Cantano - Deborah Paci - Fausto Pietrancosta - Alessandro Salvador - Matteo Tomasoni - Luca Zuccolo

Diritti: gli articoli di Diacronie. Studi di Storia Contemporanea sono pubblicati sotto licenza Creative Commons 3.0. Possono essere riprodotti e modificati a patto di indicare eventuali modifiche dei contenuti, di riconoscere la paternità dell'opera e di condividerla allo stesso modo. La citazione di estratti è comunque sempre autorizzata, nei limiti previsti dalla legge. 